\title{
Irlandeses en México: algunos aspectos de su integración económica y social, siglos XIX y XX
}

\author{
Irish in Mexico: some aspects of their economic and social \\ integration, 19th and 20th centuries
}

\begin{abstract}
Martín Pérez Acevedo*
Instituto de Investigaciones Históricas de la Universidad Michoacana de San Nicolás de Hidalgo Morelia - Michoacán - México
\end{abstract}

* Doctor en Humanidades por la Universidad Jaume I, Castellón de la Plana, España. Profesor-investigador Titular "C" de Tiempo Completo en el Instituto de Investigaciones Históricas, Departamento de Historia de México, Universidad Michoacana de San Nicolás de Hidalgo (Morelia, Michoacán, México). E-mail: mpacevedo63@yahoo.com.mx

** Agradezco a Mónica Pulido Echeveste y a Alejandra Ceja Macnaught el apoyo en la localización y captura de información en la Hemeroteca Nacional, Archivo General de la Nación y Archivo Histórico del Distrito Federal de la Ciudad de México. A Martha Patricia Pérez Acevedo, por su apoyo incondicional. 


\title{
Irlandeses en México: algunos aspectos de su integración económica y social, siglos XIX y XX
}

\author{
Martín Pérez Acevedo
}

\section{Resumen}

Después de que México se incorporó al concierto internacional de las naciones, a partir de 1821, la presencia de irlandeses se advierte en la minería, comercio y deuda pública, ya en el plano personal o como agentes de empresas británicas en el país. De igual manera este colectivo formó parte de proyectos colonizadores para poblar el norte de México, y finalmente quedó constancia de su arribo en la migración individual bajo modestos indicadores. El éxito en los negocios e influencia social y política estuvo reservado para algunos de ellos a lo largo del siglo XIX, sobre todo en el último tercio de la centuria.

En la década de 1910, las vicisitudes de la Revolución Mexicana y de la Gran Guerra limitaron la movilidad de ambos lados del Atlántico y, con ello, la continuidad en el ingreso de irlandeses a suelo mexicano, problema este último que persistió en la década siguiente debido al complejo escenario político irlandés, y la crisis económica internacional del segundo lustro de la década de 1920. Gracias a la información del Registro Nacional de Extranjeros (1925), fue posible realizar un rastreo de las particularidades de la presencia de irlandeses. En este sentido, las fichas de registro nos permitieron precisar sus lugares de procedencia, los mecanismos migratorios utilizados, los centros urbanos y rurales donde se establecieron, así como el tipo de actividades económicas que desempeñaron, es decir, la diversidad cotidiana que de una u otra manera deja entrever el proceso de integración con la sociedad receptora.

\section{Palabras clave}

inmigración, extranjeros, irlandeses, registro nacional 
Dentro de los diversos colectivos de extranjeros que se establecieron en México a lo largo del siglo XIX, el estudio de los irlandeses no ha sido abordado en detalle por los especialistas que desde parámetros económicos, sociales, demográficos y culturales se han ocupado de las minorías no nacionales. ${ }^{1}$ En el mejor de los casos, las aproximaciones que se han hecho sobre el tema se engloban en el análisis de los británicos. La única variante en la materia la constituyen las investigaciones sobre un grupo regional muy específico procedente de Gran Bretaña, como fueron los trabajadores de las minas del Real del Monte procedentes de Cornwall, que eran conocidos como cornish. ${ }^{2}$ Por lo tanto, el objetivo de este trabajo se enfocará en puntualizar algunos aspectos concretos de la presencia de los irlandeses en México en los siglos XIX y XX, con el fin de brindar elementos generales para establecer un perfil aproximado del colectivo, así como de sus particularidades o similitudes con otros grupos de extranjeros establecidos en el país.

De esta manera pretendemos hacer el seguimiento a los irlandeses en México a través de algunos registros censales locales y nacionales, información que cubre el último tercio del siglo XIX y primeras décadas del XX. Sobre todo nuestra atención se centrará en los materiales del Registro Nacional de Extranjeros establecido en 1925, -que se encuentran bajo el resguardo del Archivo General de la Nación- que de una u otra forma contienen los antecedentes de la estadía de algunos

1 Sobre la producción historiográfica de la presencia de extranjeros en México véase PLA, Dolores y Guadalupe ZÁRATE (et al). Extranjeros en México (1821-1990). Bibliografía. México: INAH, 1994; PÉREZ ACEVEDO, Martín. Inmigrantes transatlánticos en México durante el Porfiriato: algunas consideraciones para un estado de la cuestión. En: RODRÍGUEZ DÍAZ, María del Rosario y Lisette Griselda RIVERA REYNALDOS (coords.). El Porfiriato y la Revolución Mexicana. Construcciones sociales, instituciones políticas y miradas desde la historiografía. Morelia: Universidad Michoacana de San Nicolás de Hidalgo, 2012. p. 29-55.

2 HERRERA, Inés (et al). Etnia y clase. Los trabajadores ingleses de la Compañía del Real del Monte y Pachuca, 1824-1906. México: INAH, 1981; RANDALL, Robert W. Real del Monte: una empresa minera británica en México. México: Fondo de Cultura Económica, 1986; BARCELÓ QUINTAL, Raquel Ofelia. Ingleses en Real del Monte: tejiendo identidades (1824-1910). En: (coord.). Extraños en tierra ajena. Migración, alteridad e identidad, siglos XIX y XX. México: Plaza y Valdés, 2009. p. 29-53. 
de ellos en la república; documentos que nos permitirán abordar con elementos más sólidos el estudio de esta minoría no nacional entre 1900 y 1945. En este sentido, la evidencia nos lleva a determinar la participación de hombres y mujeres en el trasvase a México, sus lugares de origen, residencia, estado civil y ocupación, con la finalidad de tener un primer acercamiento desde una perspectiva social a este colectivo y su interacción dentro y fuera de su grupo.

\section{Perspectivas generales de los irlandeses en México, siglo XIX}

Después de la consumación de la independencia en 1821, uno de los principales problemas que México afrontó fue el despoblamiento de grandes extensiones de tierra en el norte y sur, así como en los litorales del Golfo de México y el Océano Pacífico, lo que limitaba toda perspectiva de explotación de sus potenciales recursos naturales. La alternativa más viable que se vislumbró para solucionar esta cuestión fue la colonización con extranjeros. En diciembre de 1824, en el marco del reconocimiento de México como nación libre e independiente por parte de la Gran Bretaña y el establecimiento de relaciones diplomáticas, se tiene registro de algunas referencias alusivas a la posible participación de doce mil familias irlandesas en proyectos de esa naturaleza que, para tal efecto, gozarían de las obligaciones y derechos que les concedía la Ley Federal de Colonización que el gobierno mexicano recién había emitido, cuyo contenido se dio a conocer en varios periódicos de Londres. ${ }^{3}$ De acuerdo a las apreciaciones de Lucas Alamán, Secretario de Relaciones Exteriores de México, y Manuel Eduardo de Gorostiza, como agente diplomático acreditado en la capital inglesa,

\footnotetext{
BERNINGER, Dieter George. La inmigración en México (1821-1857). México: Secretaría de Educación Pública, 1974. p. 53-53; GONZÁLEZ NAVARRO, Moisés. Los extranjeros en México y los mexicanos en el extranjero 1821-1970. México: El Colegio de México, 1993. vol. I. p. 55-56 141. En los años siguientes se presentaron otras propuestas tendientes a fomentar la colonización de algunas regiones del norte del país con irlandeses, iniciativas que contaban tanto con el aval de las autoridades mexicanas como con el respaldo de agentes ingleses, sin que se lograran mayores resultados. Uno de los casos más significativos de asentamiento de irlandeses en Texas se presentó en una colonia que se estableció en el margen del río de las Nueces.
} 
los irlandeses (entre otros colectivos europeos) eran uno de los grupos más apropiados para la colonización de Texas. ${ }^{4}$

A la opción de ingreso que representaba la colonización se sumó una vía más factible para los irlandeses - lo mismo que para escoceses e ingleses en general-, como era la movilización laboral que implementaron entre 1824 y 1826, siete compañías británicas que se organizaron para reactivar y explotar algunas de las minas más importantes del país. ${ }^{5}$ En este sentido se tienen referencias de la participación de trabajadores procedentes de Irlanda en las minas de Real del Monte, ${ }^{6}$ Fresnillo, Guanajuato y Bolaños, ${ }^{7}$ así como en Tlalpujahua, ${ }^{8}$ en las que realizaron labores especializadas en la extracción del mineral. El arribo y permanencia de irlandeses en estas negociaciones se mantuvo constante entre las décadas de 1830 y 1840 en la Compañía de Bolaños, la Compañía del Real del Monte y la Compañía Anglo Mexicana, hasta que concluyeron los contratos con los dueños de las minas o bien, en su defecto, se liquidaron en 1849 por las pérdidas sufridas.

La presencia de irlandeses en México en las crónicas de viaje de algunos ingleses no pasó desapercibida, lo que nos habla de que además de las tentativas de colonización y la migración de trabajadores tempo-

4 BERNINGER, Dieter George. Op. Cit., p. 54-57, 62-63. Con la finalidad de concretar resultados se llegó a plantear la fundación del Banco Nacional de Colonización Indígena y Extranjera para sufragar los costos de la movilización.

5 GONZÁLEZ NAVARRO, Moisés. Los extranjeros en México y los mexicanos en el extranjero 1821-1970. México: El Colegio de México, 1993. vol. I. p. 64.

6 De acuerdo con Raquel Barceló, entre 1826 y 1827 el comisionado en jefe de Real del Monte solicitó al Comité de la Compañía Británica de Real del Monte, con sede en Londres, se le enviaran barreteros y mineros irlandeses a dicho centro minero; la propuesta fue atendida con trabajadores de Cornwall. Véase BARCELÓ QUINTANAL, Raquel (coord.). Op. Cit., p. 35.

7 HERRERA, Inés (et al). Etnia y clase. Los trabajadores ingleses de la Compañía del Real del Monte y Pachuca, 1824-1906. México: INAH, 1981.p. 7-12. RANDALL, Robert W. Real del Monte: una empresa minera británica en México. México: Fondo de Cultura Económica, 1986. p. 222-242.

8 Archivo General de la Nación, México, (citado en adelante AGN), Ramo Relaciones Exteriores, Siglo XIX, 1826, Volumen 36, Expediente 22, f. 20. Este documento hizo alusión a las facilidades de tránsito que las autoridades del país deberían dar a los empleados británicos, así como a prusianos, franceses y españoles que arribarían al país como parte de la estructura administrativa de la Compañía Minera de Tlalpujahua. 
rales a los centros mineros se sumó una decisión de carácter personal, como lo demuestra la migración individual para venir a México. En este sentido habría que destacar que George Francis Lyon en su libro Fournal of a residence and tour in the Republic of Mexico in the year 1826, nos habla de un religioso irlandés (el padre Macdonald) en el Colegio de Nuestra Señora de Guadalupe, en Zacatecas. ${ }^{9}$ Asimismo, en las apreciaciones de algunos funcionarios del gobierno mexicano de la época, se recogen comentarios alusivos a los irlandeses, como en su momento lo hizo el general Manuel Mier y Terán, quien al recorrer el norte de México a su paso por Matamoros, Tamaulipas, anotó que la villa tenía calles anchas con casas de ladrillo, muchas de ellas propiedad de extranjeros, entre los que figuraban irlandeses. ${ }^{10}$

De acuerdo a las puntualizaciones anteriores se advierte que a pesar de los esfuerzos del gobierno mexicano, así como de compañías colonizadoras nacionales y extranjeras, no se logró un ingreso numeroso de irlandeses bajo la categoría de colonos. Por el contrario, se perfiló un modesto flujo migratorio individual, tendencia que en buena medida también se observaba con otros grupos de extranjeros provenientes de Europa que arribaban a México procedentes de Francia, España y Alemania. Conforme transcurrió el siglo XIX, Irlanda se proyectó en el contexto europeo como el país por excelencia de emigrantes gracias a la interacción de factores como la plaga de las patatas en 1846 y 1847 y la alta mortandad que ésta generó; ${ }^{11}$ la mayor división de las tierras

9 LYON, G. F. Residencia en México. 1826. Diario de una gira con estancia en la República de México. México: Fondo de Cultura Económica, 1984. p. 105.

${ }^{10}$ Diario de viaje de la Comisión de Límites que puso el gobierno de la república, bajo la dirección del Exmo. Sr. general de división D. Manuel Mier y Terán, México, Tipografía de Juan H. Navarro, 1850, p. 148-149, citado por GONZÁLEZ NAVARRO, Moisés. Op. Cit., p. 122.

${ }^{11}$ GALLAHGER, Thomas. Hambre en Irlanda: la elegía de Paddy. Madrid: Langre, 2007. El autor menciona que en 1845 se presentó una sensible reducción en la cosecha de papas en Irlanda, lo que fue el preludio de la crisis que se padeció al año siguiente. Gallagher expone los efectos de la plaga en la cosecha de papas de 1846 (phytophthora infestans), sobre todo hizo énfasis en la problemática social (aumento en los índices del robo, especulación y de la orfandad, entre otros ) y sanitaria (escorbuto, hidropesía por hambre, disentería y otros padecimientos) que generó a raíz de la hambruna que movilizó a la población del campo a la ciudad y finalmente a migrar en 
de cultivo y el aumento en el costo de los arrendamientos de éstas, entre otros elementos, que devinieron en una masiva movilización transatlántica conformada por arrendatarios, campesinos, trabajadores del campo y sirvientes cuyo destino primordial fue los Estados Unidos. ${ }^{12}$ Los irlandeses ingresaron a Norteamérica por los puertos del nordeste desde donde, poco a poco, pasaron a la parte septentrional del país. A pesar de su origen rural se incorporaron sin mayores problemas en obras de construcción de ciudades, mientras que otros se emplearon en el servicio doméstico y una minoría se hizo de un lugar en cargos públicos. ${ }^{13}$ Ahora bien, aunque es complicado definir con mayores elementos el perfil de los irlandeses dentro de la migración inglesa en México en la primera mitad del siglo XIX, la trayectoria individual de algunos de ellos en el ámbito económico vendría no solo a hablarnos de sus logros e influencia, sino de la presencia de individuos de esta procedencia en el conjunto de intereses británicos mercantiles, financieros y diplomáticos en el país. ${ }^{14}$ Entre los casos que ejemplifican lo anterior habría

condiciones poco favorables, ya que una alta cifra de viajeros falleció durante la travesía transatlántica a causa del tifus "fiebre del buque". Por otra parte, Gallagher subraya la poca atención que prestó el gobierno británico a la hambruna en Irlanda (Ley de ayuda a los pobres) dentro de su política económica al no permitir la exportación de alimentos, así como al limitar la ayuda internacional.

${ }^{12}$ BADE, KLAUS J. Europa en movimiento. Las migraciones desde finales del siglo XVIII hasta nuestros días. Barcelona: Crítica, 2003. p. 89-90, 125-127. La migración irlandesa reviste una singular diferencia respecto a la movilización transatlántica inglesa en general, ya que fue la más numerosa dentro del contexto británico, -e incluso del resto de los países europeos de esos años- asimismo sobresalió por los pocos retornos. Según Bade, entre 1815 y 1845 ya había emigrado 1,5 millones de irlandeses, la mayoría a Estados Unidos, mientras que el resto lo había hecho a Inglaterra, Escocia y País de Gales. Más tarde en el periodo comprendido entre 1846-1856, una quinta parte de la población total irlandesa, es decir, 1,75 millones, emigraron a América del Norte, cifra que continuó en aumento desde el último tercio del siglo XIX hasta la segunda década del siglo XX.

${ }^{13}$ MORISON, Samuel Eliot (et al). Breve Historia de los Estados Unidos. México: Fondo de Cultura Económica, 1987. p. 277-278.

${ }^{14}$ HEATH, Hilarie J. Los primeros escarceos del imperialismo en México. Las casas comerciales británicas, 1821-1867. Historias, México, n. 22, pág. 77-89, 1989. La autora señala que Barrón y Forbes junto con la negociación Manning y Marshal y, más tarde bajo la razón social Manning y Mackintosh, fueron las empresas británicas más importantes en el país durante la primera mitad del siglo XIX, ya que sus actividades se prolongaron por espacio de casi tres décadas. Para mayores 
que mencionar los trabajos del irlandés W. Eustace Barrón y William Forbes al frente de la firma mercantil Barrón y Forbes, cuyo centro operativo era Tepic - actual estado de Nayarit -

La cartera de negocios de Barrón y Forbes comprendía transacciones mercantiles con perlas, prácticas que se realizaban dentro y fuera de cauces legales. De vital importancia dentro de sus operaciones figuraron la importación y exportación, sobre todo de plata y azogue; rubros en los que actuaron como propietarios de la mina de mercurio llamada Nuevo Almadén en California, cuya producción a mediados del siglo XIX rivalizó con el monopolio internacional en la producción y venta de mercurio de la familia Rothschild. ${ }^{15}$ En torno a este fundo se organizó la compañía comercial Bolton Barrón and Company, que a inicios de la década de 1860 proveía de azogue a la Quicksilver Mining Company. Como parte complementaria del éxito de las firmas Barrón y Forbes así como de Bolton Barrón Company, habría que destacar la función que Barrón desempeñó como cónsul de Inglaterra en Tepic y en el puerto de San Blas. ${ }^{16}$ En el transcurso de la segunda mitad del siglo XIX, la Barrón y Forbes diversificó sus transacciones, ya que figuraron como propietarios de haciendas y ranchos, fábricas textiles y unidades agroindustriales en distintas localidades del territorio de

detalles sobre la trayectoria de la última negociación arriba mencionada véase MEYER, Rosa María. Los ingleses en México, la casa Manning y Mackintosh (1824-1852). Historias, México, n.16, 1987, pág. 57-71.

${ }^{15}$ HERRERA CANALES, Inés. Mercurio para refinar la plata mexicana en el siglo XIX. Historia Mexicana, México, vol. XL, n. 1, pág. 27-51, 1990 La familia Rothschild mantenía el control de la producción y comercialización de azogue de la mina española de Almadén. La base de la relación de la explotación de ese recurso se dio a través de empréstitos que los Rothschild otorgaron al gobierno español.

${ }^{16}$ PARRA, Alma Laura. Presencia inglesa en México durante el siglo XIX. Historias, México, n.33, pág. 13-20, 1995. La autora menciona que los inicios de la negociación fueron en la ciudad de Guadalajara, en donde se ocuparon de la especulación de bienes raíces. HERRERA CANALES, Inés. Comercio y comerciantes en la costa del Pacífico a mediados del siglo XIX. Historias, México, n. 20, pág. 133-134, 1988. De acuerdo con Herrera, James R. Bolton era cónsul norteamericano en Mazatlán, quien a su vez mantenía nexos mercantiles en California, contactos que les fueron favorables a ambos ya que participaron de las favorables condiciones que ofrecía la fiebre del oro en California y, por ende, la explotación de los metales preciosos. 
Tepic, así como participando en el dinámico circuito mercantil encabezado por el puerto de San Blas y Mazatlán en el abasto de diversos productos a los veneros auríferos californianos de la década de $1840 .{ }^{17}$

Otro ejemplo más de la emigración irlandesa individual en el siglo XIX fue el de Patrick Mullins, mejor conocido como Patricio Milmo, quien tuvo una destacada actuación en el mundo de los negocios. A partir de 1849 Milmo inició sus actividades mercantiles en la ciudad de Monterrey, las que en la medida que le reportaron beneficios se extendieron más tarde a Piedras Negras (Coahuila) y Matamoros (Tamaulipas). Las perspectivas se tornaron favorables para el comerciante irlandés en medio de las eventualidades de la Guerra de Secesión de los Estados Unidos (1861-1863), ya que participó de las transacciones que desde el estado de Texas realizaban comerciantes y propietarios norteamericanos a través de la línea fronteriza que se compartía con Nuevo León. La otra fuente de capital de Milmo fue el préstamo, ya que puso sus recursos monetarios a disposición de una amplia y selecta clientela, entre cuyos deudores incluso se contó al gobierno del estado de Nuevo León aquejado por los avatares militares de la Guerra de Reforma (1856-1859) y más tarde los efectos de la Intervención Francesa y el Imperio de Maximiliano (1862-1867) de los que no estuvo exento el noreste del México. Además del éxito en los negocios que Milmo logró en poco tiempo, la integración social la alcanzó en 1857 a través del matrimonio con Prudencia Vidaurri, hija de Santiago Vidaurri, quien era el gobernador del estado de Nuevo León-Coahuila. ${ }^{18}$

${ }^{17}$ LUNA JIMÉNEZ, Pedro y Mario CONTRERAS VALDEZ. Las inversiones extranjeras en Nayarit. En OLVEDA, Jaime (ed.). Inversiones y empresarios extranjeros en el noroccidente de México, siglo XIX. Guadalajara: El Colegio de Jalisco, 1998. p. 122.

${ }^{18}$ CERUTTI, Mario. Patricio Milmo, empresario regiomontano del siglo XIX. En. CARDOSO, Ciro F. S. Formación y desarrollo de la burguesía en México. Siglo XIX. México: Siglo XXI Editores, 1979. p. 231-266; CERUTTI, Mario. El préstamo prebancario en el noreste de México: la actividad de los grandes comerciantes de Monterrey (1855-1890). En: LUDLOW, Leonor y Carlos MARICHAL (eds.). Banca y poder en México (1800-1925). México: Grijalbo, 1986. p. 119-164. De acuerdo a los datos obtenidos por Cerutti, Patricio Milmo nació en el condado de Sligo, parroquia de Ballysodere en 1826 y sus padres fueron Dermott Milmo y Sara O’Dowd. Murió en México en 1899. Patricio Milmo, como otros extranjeros en el país fueron promotores 
Durante el régimen del general Porfirio Díaz, los negocios de Milmo se proyectaron hacia nuevos rubros, como el crédito institucionalizado a través de Milmo National Bank, que en la década de 1880 operaba en Laredo-Texas bajo la gerencia de su hermano Daniel. De igual manera participó como accionista y fundador del Banco Mercantil de Monterrey en 1899. Otro sector hacía el que se orientaron los recursos económicos del hombre de negocios irlandés fue la adquisición y explotación de haciendas y ranchos en los estados de Nuevo León, Coahuila y Tamaulipas, que se especializaron en la ganadería y en la explotación de carbón mineral. De igual manera una parte significativa de la fortuna familiar se colocó en el ramo industrial, a saber, como fueron la Sociedad Mercantil La Esperanza S. A., que elaboraba derivados de la semilla de algodón en la Comarca Lagunera (1887), la Compañía Minera de Fierro Mexicana (1887), Compañía Minera, Fundidora y Afinadora de Monterrey S. A (1890) y la Compañía Industrial de Monterrey (1892). ${ }^{19}$

También en la capital del estado de Nuevo León y su amplio radio de acción regional en el noreste del país, participaron en su variado ámbito económico los hermanos Francisco y Santiago Belden de origen irlandés. Muy probablemente la presencia de los Belden sea producto de las cadenas migratorias en las que el paisanaje fue el factor que interactuó; mecanismo en el que Patricio Milmo fue el enlace para que el primero de los Belden viajara a México en la década de 1870 y, más tarde, figurara como su socio en algunos negocios. Después Santiago hizo lo propio al lado de Daniel Milmo, quien a su vez respondió

de la migración familiar en cadena, ya que al parecer llamó a su hermano Daniel, quien en 1869 residió en Matamoros, Tamaulipas, atendiendo una casa comercial bajo la firma "Daniel Milmo y Compañía”, que se liquidó en 1878. Entre 1874 y 1878 Daniel se asoció con el irlandés Santiago Belden en una sociedad mercantil que operó en Ciudad Guerrero, Tamaulipas.

${ }^{19}$ CERUTTI, Mario. El préstamo prebancario en el noreste de México: la actividad de los grandes comerciantes de Monterrey (1855-1890 Op. Cit.p. 119-164; CERUTTI, Mario. Burguesía y capitalismo en Monterrey (1850-1890). México; Claves Latinoamericanas, Facultad de Filosofía y Letras, Universidad Autónoma de Nuevo León, 1989. Consúltese el capítulo La formación del capital preindustrial (1850-1890). 
al llamado familiar en 1869 y, por lo tanto, completó de esta manera la movilidad transatlántica. Además de los nexos que los Belden tuvieron con los Milmo, sus transacciones las complementaron con otros importantes empresarios nacionales y extranjeros residentes en Monterrey y en estados vecinos, entre los que destacaban integrantes de las connotadas e influyentes familias Armendaíz, Calderón-Muguerza, Ferrara, Hernández-Mendirichaga, Madero, Rivero, Sada MuguerzaGarza y Zambrano. ${ }^{20}$

La singularidad de los casos de los irlandeses que se establecieron en México en la primera mitad del siglo XIX, cuya trayectoria les permitió alcanzar el éxito económico, contrasta con la mayoría de sus coterráneos que distaron de sobresalir en los rubros mercantiles, crediticios, industriales y diplomáticos. En efecto, entre los indicadores a los que podemos hacer alusión figura la información del censo de población que se realizó en enero de 1848 en la ciudad de México, en medio de las vicisitudes de la ocupación norteamericana. El número de extranjeros en la capital fue de 2,006 individuos, entre los que había 103 "ingleses"; total parcial que dio cuenta de nueve irlandeses, tres mujeres y seis hombres. ${ }^{21}$

${ }^{20}$ CERUTTI, Mario. Burguesía y capitalismo en Monterrey (1850-1890). Op. Cit., 1989. Véase los apéndices IV y V del capítulo La formación del capital preindustrial (1850-1890). Al respecto vale la pena mencionar que entre los hombres de negocios arriba mencionados fueron socios en la Compañía Minera, Fundidora y Afinadora Monterrey, Compañía Minera de San Pablo, Compañía Minera La Equitativa y Anexas, Compañía Ladrillera Unión, Inversiones de Monterrey, Empresa Editorial de Monterrey, Compañía del Ferrocarril Urbano y Local de Monterrey a Santa Catarina, Banco de Nuevo León, Compañía Industrial Jabonera de la Laguna, entre otras.

${ }^{21}$ GAYÓN CÓRDOVA, María. Extranjeros en la ciudad de México en 1848. En: SALAZAR ANAYA, Delia (coord.). Imágenes de los inmigrantes en la ciudad de México, 1753-1910. México: Plaza y Valdés Editores, CONACULTA, INAH, 2002. p. 140-141. De acuerdo con la autora se advierten elementos contrastantes de endogamia, exogamia en las relaciones matrimoniales entre los extranjeros residentes en la capital del país. En el caso del pequeño grupo de irlandeses, Gayón Córdova nos ejemplifica esa cuestión con el matrimonio Jaquins integrado por el irlandés Juan y la escocesa Luisa, quienes tuvieron cinco hijos que en el momento del empadronamiento fueron reconocidos como mexicanos. $\mathrm{Al}$ respecto consideramos que en un buen número de enlaces matrimoniales entre extranjeros de la misma procedencia o, bien en su defecto de otra nacionalidad, 
Respecto a las actividades económicas que desarrollaban los "ingleses" figuró en primer plano el comercio en su acepción más general, el ejercicio de algún oficio - escultores-, o bien, como propietarios de un local para el juego de bolos. A pesar de las limitantes informativas en el orden económico, Gayón Córdova nos dice que los súbditos británicos eran los que pagaban, dentro de los europeos residentes en la ciudad, las rentas más altas por las habitaciones que ocupaban -casas y accesorias-, lo que nos habla del poder adquisitivo que tenían tentativamente en conjunto. Dichos espacios se localizaban en las inmediaciones de la plaza principal de la ciudad y al sur de la catedral, que concentraban el principal escenario del intercambio mercantil y el ejercicio de oficios y servicios..$^{22}$ La presencia de irlandeses en la capital del país se incrementó en virtud a la defección del Batallón de San Patricio, ya que sus integrantes se sumaron a las fuerzas mexicanas que defendían el lugar. Tras la conclusión de las hostilidades los sobrevivientes se unieron al ejército nacional, mientras que otros se dedicaron al ejercicio de alguna actividad artesanal. ${ }^{23}$

Las referencias alusivas a los irlandeses en México, al igual que de los extranjeros en general, gradualmente se hicieron presentes en la información relativa a la población nacional, cuyo punto de partida formal se realizó durante la presidencia del general Manuel González (1880-1884), ya que se fundó en 1882 la Dirección General de Estadística, lo que representó el primer paso en el recuento sistemático de la vida pública del país. Entre los trabajos iniciales de la dependencia gubernamental figuró la elaboración del padrón de la municipalidad de México que se realizó en ese año, documento que además de que proporcionó datos de los habitantes de la demarcación administrativa

sus descendientes fueron reconocidos como nacionales del país de acogida. Esta decisión muy probablemente se tomó en función a que habían decidido no regresar a sus lugares de origen.

22 GAYÓN CÓRDOVA, María. Op. Cit., p. 145, 159-160.

${ }^{23}$ Ibidem, p. 161-162. La autora nos dice que en la batalla de Churubusco, en las inmediaciones de la capital, setenta irlandeses del Batallón de San Patricio fueron ahorcados, el resto de la tropa fue marcado en la mejilla con un hierro candente con la letra D, alusiva a desertores, quienes rechazaron regresar a los Estados Unidos. 
mencionada, contempló referencias sobre los extranjeros residentes en la capital de la república, entre los que figuraron 146 ingleses. ${ }^{24}$

De nueva cuenta la generalidad en que fue considerado el grupo se convirtió en una limitante para determinar el número de irlandeses; cifra que reportó un descenso, pues se contabilizó a cuatro de ellos. ${ }^{25}$ El perfil socioeconómico de los "ingleses" observó algunas variantes en el Padrón de 1882, lo que nos plantea un cambio cualitativo en su conformación, ya que si bien se mantuvieron presentes en el ejercicio mercantil también se ocuparon como artesanos y productores, administradores, profesionistas, servicios educativos y particulares, entre otros. ${ }^{26} \mathrm{Al}$ margen de los datos del censo aludido, un aspecto a desta-

${ }^{24}$ MORALES, María Dolores. La población extranjera en la ciudad de México en 1882. En: SALAZAR ANAYA, Delia (coord.). Imágenes de los inmigrantes en la ciudad de México, 17531910. México: Plaza y Valdés Editores, CONACULTA, INAH, 2002. p. 177-224. El número de extranjeros en la capital era de 3718 . En el caso inglés se advierte un ligero incremento en poco más de tres décadas, con total de 43 individuos, sobre los que no es posible determinar que se tratará de hombres o mujeres que arribaron en dicho lapso de tiempo o, bien, de nuevo ingreso. La autora hace una interesante puntualización al señalar la existencia de un buen número de niños, que muy probablemente nacieron en el país o, que, en su defecto, ingresaron en compañía de sus padres. Para 1890, el número de residentes ingleses se había incrementado a 360, según el censo de la municipalidad de ese año. Respecto al perfil socioeconómico de éstos se destacó su labor en la diplomacia, los negocios financieros, mercantiles, obras públicas e inversión foránea, así como trabajadores calificados en la minería, industria eléctrica y petrolera, ferrocarriles y en las obras públicas de mayor calado en la ciudad. Sobre el particular consúltese SALAZAR ANAYA, Delia. Extraños en la ciudad. Un acercamiento a la inmigración internacional a la ciudad de México, en los censos de 1890, 1895, 1900 y 1910- En __(coord..). Imágenes de los inmigrantes en la ciudad de México, 1753-1910. México: Plaza y Valdés Editores, CONACULTA, INAH, 2002. p. $225-250$.

${ }_{25}$ Archivo Histórico del Distrito Federal, México, en adelante citado como (AHDF), Fondo Ayuntamiento, Padrón 1882, volúmenes 3424, 3427, 3429. Hasta el momento contamos con la referencia de cuatro irlandeses. La reducción puede ser atribuible al fallecimiento de individuos de esa procedencia, aunque también habría que considerar su retorno al lugar de origen, o bien, su cambio de domicilio a otro centro urbano del país.

${ }^{26}$ MORALES, María Dolores. Op. Cit., p. 192, 198. Dentro los rubros que atendían los ingleses se encontraban ramos que dejan en claro su participación en sectores modernos dentro del ámbito urbano, como eran la empresa de gas de hidrógeno que atendía el alumbrado público de la capital. En tanto que en su labor como artesanos y productores se encontraban quienes trabajaban en plomerías, procesando metales no preciosos y carroceros. Mientras que los que se desempeñaban 
car del colectivo sería la presencia transitoria de irlandeses en las obras públicas más importantes que se desarrollaron durante el régimen del general Porfirio Díaz, entre los que sobresalieron los trabajos que en el transcurso de la década de 1890 se emprendieron en la construcción del gran canal de desagüe de la capital del país, así como los realizados en el puerto de Veracruz; proyectos que quedaron bajo la dirección de las empresas del contratista británico Weetman D. Pearson. ${ }^{27}$

Más tarde los censos nacionales de población de 1895, 1900 y 1910, que estuvieron bajo la supervisión de la Dirección General de Estadística, nos indican que se registró un aumento en el ingreso de extranjeros en el país - que obedecía al desarrollo económico implementado por el régimen del general Díaz, la estabilidad política, el reconocimiento internacional del gobierno porfirista y al marco normativo favorable a la inmigración, así como a la movilidad poblacional transatlántica que observó Europa entre 1880 y 1930-, tendencia que igualmente estuvo presente en los individuos procedentes de la Gran Bretaña, al grado que en México se convirtieron en el segundo grupo de inmigrantes más numeroso procedente del viejo continente, tan solo superado por España; condición que derivó en la presencia de individuos de esa procedencia en todos los estados de la república, con un marcado predominio de varones sobre mujeres. ${ }^{28}$ De acuerdo a la estructura de los recuentos poblacionales y a la composición política y

como administradores comprendieron desde empleados ferrocarrileros hasta directivos del Banco de Londres, México y Sudamérica, por mencionar algunos casos.

${ }^{27}$ CONNOLLY, Priscila. El contratista de don Porfirio. Obras públicas, deuda y desarrollo desigual. México: El Colegio de Michoacán, Universidad Autónoma Metropolitana/Azcapotzalco, Fondo de Cultura Económica 1997.

${ }^{28}$ Para más detalles sobre el perfil cuantitativo de los extranjeros en México véase SALAZAR ANAYA, Delia. La población extranjera en México (1895-1990). Un recuento con base en los Censos Generales de Población. México: INAH. 1996. Entre 1895, 1900 y 1910, el número de ingleses en el país fue de 3,167, 2,802 y 5,264 respectivamente, lo que nos indica que la cifra más alta se alcanzó en la primera década del siglo XX. No sería sino hasta el censo de 1930 en que dentro del rubro de ingleses se contempló su diferenciación conforme a su procedencia, es decir, Escocia, Irlanda y Honduras Británica. En el recuento de ese año se dio cuenta de 50 hombres y 25 mujeres irlandeses. 
territorial del Reino Unido, las cifras concentradas en estos instrumentos de nueva cuenta no hicieron distinción de ningún tipo respecto a cada uno de los componentes de esa nacionalidad y, por lo tanto, no se determinó el número de irlandeses.

A pesar de las generalidades que se desprenden de la información censal obtenida entre 1895 y 1910, la consulta de otros registros documentales nos permite ampliar la panorámica sobre el colectivo "inglés". En efecto, las tarjetas de identificación del Registro Nacional de Extranjeros, nos han permitido detectar el arribo a México de jóvenes irlandeses de ambos sexos, cuyas edades fluctuaban entre los 20 y 26 años. De acuerdo a los datos proporcionados a las autoridades hemos detectado casos en los que el ciclo migratorio familiar se cerraba con el ingreso de algunas mujeres que se reencontraban con su cónyuge, quien les había antecedido en el trasvase transoceánico, como se desprende del caso de Annie N. de Walker, ${ }^{29}$ quien entró al país por Laredo, Tamaulipas, en 1896. En muy pocas ocasiones la migración femenina no estuvo asociada con el matrimonio, sino con una iniciativa individual tendiente a mejorar su condición respecto al lugar de origen, como se advierte con Kilty Fitzpatric, mujer soltera que en 1907 llegó a México a los 23 años, para en breve ocuparse de actividades mercantiles en la capital del país. ${ }^{30}$ También en el proceso migratorio de los irlandeses se detectó movilidad de individuos que realizaban alguna actividad profesional, como se puede apreciar con el ensayador químico Frederick Boyd, que se instaló en 1899 en el

\footnotetext{
${ }^{29}$ AGN, Registro Nacional de Extranjeros, Ingleses, caja 3. Anne N. de Walter nació en Lonford, Irlanda, en el año de 1870.

${ }^{30}$ AGN, Registro Nacional de Extranjeros, Ingleses, caja 17. Kilty era originaria de Belfast, en donde nació en 1884. Según las referencias documentales no contrajo nupcias, lo que nos habla de la poca oferta matrimonial entre individuos de la misma nacionalidad en México y, por ende, su renuencia a casarse con algún miembro de la sociedad receptora evidenciando la propensión endogámica.
} 
Mineral de Cata, estado de Guanajuato; ${ }^{31}$ similar condición se reportó con Archibald Bartran. ${ }^{32}$

Sin mayores divergencias en el proceso migratorio que se observó respecto a otros grupos de extranjeros en México, los irlandeses conjugaron elementos como el paisanaje y los nexos afectivos para brindarle al recién llegado las mejores condiciones para su integración en la sociedad receptora. La migración en cadena adquirió singular importancia cuando intervinieron otros factores que permitieran reforzar los vínculos sociales, económicos e incluso políticos a través del matrimonio. El caso que mejor nos ilustra este entramado de relaciones sería de nueva cuenta la familia Milmo Vidaurri y sus nexos en el mundo económico y político del nordeste del país, ya que nos ofrece un ejemplo a considerar a través de Francisco O'Hart, quien al igual que Milmo era originario de Sligo.

Consideramos que la presencia de O’Hart en Monterrey en 1902, no era fortuita, pues sin mayores dudas obedecía a la necesidad de los Milmo de contar con un individuo de toda su confianza para atender algunos negocios. Al poco tiempo de haberse establecido en la ciudad de Monterrey Francisco O'Hart contrajo nupcias con Leonor Milmo Vidaurri, lo que en breve le permitió figurar como un importante propietario residente en la capital del estado de Nuevo León. ${ }^{33}$ De acuerdo al patrón matrimonial de los Milmo, habría que destacar que priorizaron el establecer vínculos con individuos pertenecientes al mundo de los negocios, lo que venía a confirmar la presencia de este grupo dentro de las más altas esferas económicas, sociales y políticas en la región.

La estabilidad política y el desarrollo económico alcanzado por el régimen del general Porfirio Díaz, se puso en entredicho tras el levantamiento armado de Francisco I. Madero en noviembre de 1910,

\footnotetext{
${ }^{31}$ AGN, Registro Nacional de Extranjeros, Ingleses, caja 5. Fredrick Boyd Keith era originario de Cashel, en donde nació en 1873.

${ }^{32}$ AGN, Registro Nacional de Extranjeros, Ingleses, caja 5. Bartran declaró llanamente haber nacido en Irlanda en 1884.

${ }^{33}$ AGN, Registro Nacional de Extranjeros, Ingleses, caja 4. Francisco O’Hart Kilgallen.
} 
lo que vino a afectar la vida y propiedad de la población civil tanto nacional como extranjera, a partir de este momento y a lo largo de la década. Los efectos de cada una de las etapas de la Revolución no fueron ajenos a los ingleses y las compañías británicas establecidas en México, ya que reportaron pérdidas y la destrucción parcial de sus intereses materiales por \$138’603.063.97, según lo demandaron en calidad de indemnización 128 reclamantes de esa nacionalidad. ${ }^{34}$ Dentro de este total si bien no nos ha sido posible determinar la presencia de irlandeses, consideramos que entre los afectados por el movimiento armado con toda seguridad se encontraron individuos provenientes de Irlanda, lo que viene a demostrar la falta de estudios sobre este grupo de extranjeros que se diluye en el colectivo bajo el carácter general de "ingleses". Esta situación incluso se evidencia entre los pocos elementos testimoniales de la época, como el de Patric O’She, cuyo relato esporádicamente hizo alusión en general a presencia de británicos en el norte de México, sobre todo vinculados a actividades agroindustriales en la región de la Comarca Lagunera. ${ }^{35}$

De acuerdo con las cifras censales de la década de 1920 se advierte un descenso en el número de "ingleses" residentes en México. La reducción obedecía a las violentas eventualidades de la Revolución, así como al llamado de súbditos de su majestad a filas en el frente europeo a partir de 1914, en medio del curso de las hostilidades de la Gran Guerra; tendencia que continuó a la baja hasta 1930, como se aprecia en el recuento población que se practicó al inicio de ese año. ${ }^{36}$ De igual manera habría que tener en cuenta las limitantes que

34 Apéndice a la Memoria de la Secretaría de Relaciones Exteriores de agosto de 1931 a julio de 1932 presentada al Congreso de la Unión por el C. Manuel C. Tellez, Secretario de Relaciones Exteriores. México; Imprenta de la Secretaría de Relaciones Exteriores, 1932. p. 704-714. El importe de las reclamaciones inglesas que el gobierno mexicano reconoció después de que concluyó sus trabajos la Comisión de Reclamaciones en diciembre de 1930 fue de \$3’795.897.53.

${ }^{35}$ O’HEA, Patric. Reminiscencias de la Revolución Mexicana, (estudio introductorio y notas de Graziella Altamirano Cozzi). México: Instituto Mora, 2012.

${ }^{36}$ SALAZAR ANAYA, Delia Op. Cit., p. 102. El número de británicos registrados en México en 1921 alcanzó la cifra de 3229, mientras que en el conteo poblacional de 1930 fue de 2946. Para el censo 
representaron para los irlandeses los problemas políticos internos, así como los que enfrentaron con la Gran Bretaña en 1916 (Rebelión de Pascua), 1919-1921(Guerra Anglo Irlandesa) y entre 1921 y 1923 la Guerra Civil Irlandesa. ${ }^{37}$

\section{Irlandeses en el siglo XX según el Registro Nacional de Extranjeros}

En marzo de 1926, el gobierno de Plutarco Elías Calles emitió la Ley de Migración, ${ }^{38}$ que entre otros lineamientos normativos obligaba a los extranjeros residentes de quince años en adelante a inscribirse en el Registro Nacional de Extranjeros. Al igual que para otros individuos no nacionales, los expedientes personales de los ir-

de 1950 se observó cierta disminución respecto a los años anteriores, pues las cifras reportaron un total de 2280 ingleses.

${ }^{37}$ CRUSET, María Eugenia. Nacionalismo y diásporas. Los casos vasco e irlandés en Argentina (1862-1922). Buenos Aires: Universidad Nacional de La Plata, Cátedra Libre de Pensamiento y Cultura Irlandesa, Ediciones Lauburu, 2015. p. 80-84.

${ }^{38}$ La Ley de Migración de marzo de 1926 derogó la Ley de Inmigración de 1908 que había emitido el gobierno de Porfirio Díaz. Entre los aspectos que normó la Ley de Migración figuraron la prohibición de ingreso de individuos al país en calidad de mano de obra, narcotraficantes, toxicómanos, prostitutas, tratantes de blancas y tráfico de indocumentados, entre otros. Más tarde se promulgó en agosto de 1930 otra Ley de Migración que en esencia mantuvo los mismos lineamientos de su antecesora -el reglamento de este corpus normativo se expidió el 14 de junio de 1932-. Entre las variantes que destacaron figuró el establecimiento de las categorías de "inmigrante" y "transeúnte", así como la creación de nuevas dependencias para atender el ingreso de extranjeros, como el Departamento de Migración y El Consejo Consultivo de Migración. Más tarde, la administración del general Lázaro Cárdenas promulgó la Ley General de Migración en agosto de 1936, que entre otras cosas se ocupó de asuntos migratorios, turismo, demografía e identificación y registro de personas. Esta ley ratificó las funciones del Registro Nacional de Extranjeros. El Registro Nacional contiene información que va de 1926 a 1950. Sobre estas cuestiones véase DIARIO OFICIAL. ORGANO DEL GOBIERNO GONSTITUCIONAL DE LOS ESTADOS UNIDOS MEXICANOS. México: Eduardo Gómez Gallardo, n. 12, 13 marzo 1926; DIARIO OFICIAL. ORGANO DEL GOBIERNO CONSTITUCIONAL DE LOS ESTADOS UNIDOS MEXICANOS. México: Froylan C. Manjarrez, n. 37, 14 junio 1932. DIARIO OFICIAL. ORGANO DEL GOBIERNO CONSTITUCIONAL DE LOS ESTADOS UNIDOS MEXICANOS. México: DIARIO OFICIAL. ORHANO DEL GOBIERNO CONSTITUCIONAL DE LOS ESTADOPS UNIDOS MEXICANOS. México: Gildardo Huerta, n.52, 29 agosto 1936. 
landeses no han sido abiertos a la consulta, por lo que la información es parcial y limitada, ya que se sujeta al contenido de las formas F. 5 y F $14 .{ }^{39}$ A diferencia de otras minorías foráneas - como los españoles, entre otros- ${ }^{40}$ los irlandeses acudieron a inscribirse en el Registro desde que se puso en marcha; particularidad a su vez concuerda en buena medida si se contrasta con el número de irlandeses que figuran en el Censo General de Población de 1930 y con la evidencia cuantitativa del Registro Nacional de Extranjeros.

De acuerdo con lo arriba señalado tenemos que los irlandeses observaron un ingreso modesto en el conjunto de la inmigración británica en México, como se aprecia en los cinco casos que se anotaron en el Registro Nacional de Extranjeros entre 1926 y 1929, flujo que de cualquier manera alcanzó sus niveles más altos en la década de 1930 con 45 inscripciones; cifra que descendió a 14 irlandeses registrados en los recuentos censales entre 1940 y 1950. El número en el mejor de los casos es relativo, ya que solamente se registraron hombres y mujeres a partir de los quince años, lo que dejó al margen de ser contabilizados a los menores de edad de las familias irlandesas, lo que de representaría un modesto incremento en el total.

Para definir el perfil del inmigrante irlandés en México entre 1926 y 1950 hemos tomado como referencia los datos que contiene el Registro Nacional de Extranjeros. Cada ficha considera los siguientes puntos: nombre, lugar de registro, fecha y lugar de nacimiento, edad, estado civil, ocupación, idioma nativo, otros idiomas, nacionalidad, religión, raza, lugar de residencia y referencias. ${ }^{41}$ El número de irlan-

${ }^{39}$ Documentos de identificación oficial expedidos por el Departamento de Migración que contaba con fotografía de frente y otra de perfil del interesado. La información comprendía la media filiación del individuo, así como datos complementarios que hacían alusión a su año de nacimiento, estado civil, profesión, oficio u ocupación, idioma, lugar de nacimiento, nacionalidad, religión, raza, lugar de residencia, entre otros.

${ }^{40}$ LIDA, CLARA E. Inmigración y exilio. Reflexiones sobre el caso español. México: Siglo XXI Editores, 1997. p. 48-49, 55-58.

${ }^{41}$ Véase AGN, Registro Nacional de Extranjeros, Ingleses. Los registros de los irlandeses se encuentran dentro de las fichas correspondientes a ingleses, en los que se localizan además las de escoceses, 
deses en el Registro Nacional de Extranjeros entre 1926 y 1950 comprendió 71 individuos, entre los que había 30 mujeres cuyo estado civil consideró a 15 casadas, 12 solteras y 3 viudas. Mientras que del total de 41 hombres había 26 casados, 14 solteros y un viudo. ${ }^{42}$

En relación con las irlandesas casadas, si bien no nos fue posible determinar en todos los casos que el esposo fuera también irlandés, si se advierte en un buen número esa condición, cuyos ejemplos nos los proporcionan Eillin O’Hara que procedía de Waterford, ${ }^{43}$ que estaba casada con Donald B. H. Coates, así como Florencia K. Buckler, que era originaria de Donagal, entre otras. ${ }^{44}$ Por lo que respecta a las viudas que emigraron a México, como fue el caso de Matilda Purcell Vda. de O’Dwyer, Carolina Chermside Vda. de Buckler y Minuie Searver, éstas en su momento estuvieron casadas con irlandeses. ${ }^{45}$ Las limitantes informativas de la ficha de registro no nos permite precisar si las mujeres padecieron la pérdida de sus esposos en México o, bien, en su defecto, migraron en esa condición civil con el propósito de ejercer alguna actividad que les permitiera obtener los medios de sobrevivencia, e inclusive formar parte de la oferta matrimonial de los migrantes irlandeses en el país, sobre todo en el caso de las más jóvenes.

\footnotetext{
galeses, británicos, así como de individuos que habían nacido en varios lugares de Asia, El Caribe y Oceanía que ostentaban esa nacionalidad, e incluso en otros países. El fondo documental lo conforman 20cajas que contienen más de seis mil registros. La identificación de los irlandeses en esa base informativa presentó algunos problemas, ya que en un buen número de casos solo se menciona como lugar de nacimiento Inglaterra, lo que no nos permitió definir la procedencia de todos.

${ }^{42}$ El total de irlandeses que localizamos en el Registro Nacional de Extranjeros que fue de 71 individuos mantiene correspondencia con los anotados en el censo de 1930, que contabilizó a 75 de ellos. La variante seguramente se trató de cuatro menores cuya edad estaba por debajo de los quince años, por lo que no quedaron comprendidos en el Registro. Otras variantes que consideramos mínimas estarían relacionadas con el número de hombres y mujeres que con toda seguridad se debía a las variables del saldo migratorio a lo largo de veinte años o, bien, en su defecto al fallecimiento de algunos de ellos.

${ }^{43}$ AGN, Registro Nacional de Extranjeros, Ingleses, caja 4, Eillen O’Hara de Coates.

${ }^{44}$ AGN, Registro de Extranjeros, Ingleses, caja 14, Florencia K. Buckler. Ingresó por Ciudad Juárez, Chihuahua, en el mes de junio de 1929.

${ }^{45}$ AGN, Registro Nacional de Extranjeros, Ingleses, caja 4, Matilda Purcell Vda. de O'Dwyer, caja 15, Carolina Chermside Vda. de Buckler, caja 18, Minuie Searver.
} 
De acuerdo con las tarjetas del Registro habría otras dos cuestiones a considerar sobre los irlandeses y sus descendientes. Las familias integradas por cónyuges irlandeses que se establecieron en México entre el último tercio del siglo XIX y las primeras cuatro décadas del siglo XX o, en su defecto, las que se formaron en estos años sin haber hecho señalamiento sobre su lugar de origen, conservaron su nacionalidad, misma que transmitieron a sus hijos nacidos en México -dato que fue bien acotado por las autoridades mexicanas en sus registros-, lo que dificulta su plena identificación. En segundo término, en las familias conformadas por un irlandés y una mujer mexicana, según la legislación mexicana, la esposa e hijos asumían automáticamente la nacionalidad del padre. Sin embargo, en las tarjetas de registro no se hizo alusión a la condición de irlandeses de los descendientes, y cuando mucho se señaló que su nacionalidad era inglesa. Un ejemplo de lo anterior lo representó la familia integrada por Francisco O'Hart y Leonor Milmo Vidaurri de O'Hart, y sus dos hijos. ${ }^{46}$ Esta situación independientemente de cualquiera de sus variantes, nos da pie a pensar que muy probablemente pudiéramos hablar de una o dos generaciones de irlandeses nacidos en México.

Otro factor importante a considerar de los irlandeses fue el renglón referente a la práctica religiosa que declararon profesar, ya que un $54 \%$ se dijo católico, mientras que un $34 \%$ se pronunció por el protestantismo. ${ }^{47}$ La edad del inmigrante irlandés es otra cuestión que merece destacarse, ya que el registro de nacimiento más antiguo correspondió al año de 1858, mientras que el más reciente fue de 1928, lo que nos permite detectar que los irlandeses que se inscribieron en el Registro Nacional nacieron entre las décadas de 1870 y 1890, es decir, que los que reali-

${ }^{46}$ AGN, Registro Nacional de Extranjeros, Ingleses, caja 1. Leonor Milmo Vidaurri de O'Hart, Patricio O’Hart y Leonor O’Hart, caja 4. Francisco O’Hart Kilgallen. En el caso de Leonor habría que señalar que nació en París, mientras que su hermano lo hizo en Monterrey. Ambos declararon tener la nacionalidad inglesa.

${ }^{47}$ AGN, Registro Nacional de Extranjeros, Ingleses. Otros de los credos que los irlandeses declararon fueron el anglicanismo, episcopales y cristianos. Dos irlandeses asentaron en sus registros no que practicaban ninguna religión, mientras que uno se dijo libre pensador. 
zaron la travesía transoceánica tenían entre 30 y 50 años; ${ }^{48}$ condición que contrasta con las tendencias de otros colectivos extranjeros que reportaban edades que rondaban entre los 10 y los 29 años, con una media de 22 años, como fue el caso de los españoles en esta misma etapa. ${ }^{49}$

Los lugares de nacimiento de los irlandeses que se inscribieron en el Registro Nacional de Extranjeros comprendieron 32 localidades tanto en Irlanda -en un caso se anotó Erin en gaélico irlandés- como en Irlanda del Norte. Los condados y pueblos de procedencia fueron Dublín, Sligo, Tipperary, Cork, Waterford, Wexford, Limerick y Longford, que en total nos dan cuenta del lugar de procedencia de 34 individuos. En tanto que de Irlanda del Norte figuraron Armagh, Antrim y Down con 9 irlandeses. Sin que se pueda precisar su procedencia regional se encontraban 16 casos, ya que como única referencia se anotó que habían nacido en Irlanda. De lo anterior se puede inferir el interés de los hombres y mujeres que se registraron en esa categoría de dar constancia de su procedencia. El principal elemento distintivo tentativo que se desprende de la migración irlandesa a México fue el carácter urbano, según se advierte en el cuadro 1 que da constancia de los lugares de origen.

\footnotetext{
${ }^{48}$ AGN, Registro Nacional de Extranjeros, Ingleses.

${ }^{49}$ GAMBOA OJEDA, Leticia. Los españoles en la ciudad de Puebla hacia 1930. En: LIDA, Clara E. (comp.). Una inmigración privilegiada. Comerciantes, empresarios y profesionales españoles en México en los siglos XIX y XX. Madrid: Crítica, 1994, p. 190-217.
} 


\section{Guadro 1}

\section{Procedencia de la migración irlandesa a México}

\begin{tabular}{|c|c|}
\hline IRLANDA & IRLANDA DEL NORTE \\
\hline Condado Dublín & Condado Armagh \\
Dublín: 15 & Lurgan: 1 \\
\hline Condado Sligo & Condado Antrim \\
Monasteraden: 1 & Ballinderry: 1 \\
Boyle: 1 & Belfast: 5 \\
Sligo: 2 & Annaghmore: 1 \\
\hline Condado Tipperary & Condado Down \\
Cashel: 1 & Portaferry: 1 \\
Nenagh: 1 & Bangor: 1 \\
\hline Condado Lonford: 1 & \\
\hline Condado Limerick: 2 & \\
\hline Condado Wexford: 1 & \\
\hline Condado Cork & \\
Millstreet: 1 & \\
Fermoy: 1 & \\
Cork: 2 & \\
\hline Condado Waterford & \\
Tallow: 2 & \\
Waterford: 1 & \\
\hline Kondado Donagal: & \\
\hline Total 33 & \\
\hline
\end{tabular}

Fuente: elaboración propia con base en AGN, Registro Nacional de Extranjeros, Ingleses.

Acerca de los lugares por los que los irlandeses ingresaron al país tenemos que lo hicieron por puertos del Golfo de México, como Veracruz, Puerto México y Tampico, mientras que por la frontera norte, principalmente arribaron por Piedras Negras (Coahuila), Ciudad Juárez (Chihuahua), y Nuevo Laredo (Tamaulipas). El punto de origen del 
viaje no siempre fue Irlanda, ya que conforme a los datos del Registro Nacional de Extranjeros, el recorrido en algunos casos se había iniciado en Colombia, La Habana y los Estados Unidos, lo que nos plantea la posibilidad de que hubiera una residencia previa en otros países. Sobre las causas de la movilidad transoceánica, los principales argumentos que se expusieron fueron: viaje de negocios, turismo, reunión familiar y trabajo temporal, que denotaba la intención de integración económica y social de los que ingresaban en esos años.

Los irlandeses que emigraron a México entre 1930 y 1950 se instalaron principalmente en la capital de la república, aunque otros de los lugares en los que se establecieron, según las fichas, fueron Monterrey (Nuevo León), Nuevo Laredo y Tampico (Tamaulipas), Torreón (Coahuila), Veracruz, Mineral de Cata y León (Guanajuato), Aguascalientes, Ciudad Juárez (Chihuahua), Durango y Mérida (Yucatán). Las localidades de destino elegidas por los irlandeses fueron de carácter urbano cuyo principal atractivo fue el ejercicio de diversas actividades económicas, entre las que destacaba el comercio, la industria, los servicios, etc., rubros que de alguna manera incentivaban su integración a la sociedad receptora.

Dentro de los datos que contienen los registros de los irlandeses, las referencias de las actividades económicas que desempeñaban para subsistir nos brindan elementos para precisar el lugar que ocuparon en la sociedad receptora, así como las diferencias que los empleos y actividades cotidianas que desarrollaban marcaron dentro del colectivo mismo. En un primer momento tanto el ejercicio de labores remuneradas como no remuneradas por los inmigrantes irlandeses matizaron las diferencias entre géneros, ya que las mujeres casadas y viudas declararon dedicarse a "su casa", "labores del hogar", o bien, dijeron no realizar ninguna. Dichas referencias nos confirman que las mujeres irlandesas en ese estado civil aparentemente circunscribían su accionar cotidiano al hogar y al cuidado de la familia. Por lo tanto eran las encargadas de mantener la economía doméstica, el cuidado de la casa y fomentar en los hijos los valores morales, religiosos, costumbres y tradiciones del lugar de origen, con 
apego a los lineamientos conductivos de género propios de la época que señalaban dichas actividades como propias de la "buena mujer". ${ }^{0}$

Por su parte las irlandesas solteras presentaban importantes variantes respecto a las casadas, ya que esta condición fue un factor que con diversos matices incidió en su integración social y económica, según sus condiciones, habilidades y/o grado de escolaridad; particularidades que cambiaban gradualmente el estereotipo de la migrante irlandesa que se ocupaba dentro del servicio doméstico como sirvienta, cocinera, lavandera, niñera, como fue característico de la migración femenina en los Estados Unidos. ${ }^{51}$ En este sentido su incorporación al mundo laboral en México se realizó con otras variantes, ya que sobre todo se ocuparon impartiendo clases de inglés, actividad que tenía demanda en familias de los sectores medios de las ciudades, que procuraban la instrucción de sus hijos con maestros particulares cuya lengua materna fuera la que se enseñaba. Dentro de este ramo cabría mencionar los casos de Mary Tarrant Hickey de Millstreet, quien ofrecía sus servicios en la capital del país desde 1926, lo mismo que Margaret Keffee. ${ }^{52}$ Mientras que en Veracruz Josefine Meskill O’Bryne atendía la enseñanza del idioma inglés, así como de alemán, italiano, francés y español. ${ }^{53}$ En una perspectiva distinta se encontrarían aquellas irlandesas que tenían una preparación técnica profesional como medio de subsistencia, como fue el caso de la estenógrafa (taquígrafa) Ida Corcoran, a cuya calificación laboral se le agregó ser bilingüe. ${ }^{54}$

\footnotetext{
${ }^{50}$ Sobre los estereotipos y funciones de género socialmente deseables en el periodo véase DUBY, George y PERROT, Michelle (dirs.). Historia de las mujeres en occidente. Madrid: Taurus, 2000, Tomos IV y V.

${ }^{51}$ Respecto al papel de las irlandesas en el servicio doméstico de las clases medias en el noreste de los Estados Unidos véase LYNCH BRENNAN, Margaret. The irish bridget: irish inmigrant women in domestic service in America, 1840-1930. New York: Syracuse University Press, 2009.

52 AGN, Registro Nacional de Extranjeros, Ingleses, caja 3, Mary Tarrant Hickey arribó a México en 1926 a la edad de 33 años, caja 8, Margaret Keffee por su parte se instaló en el país en 1936.

${ }^{53}$ AGN, Registro Nacional de Extranjeros, Ingleses, caja 12, Josefine Meskill O’Bryne.

${ }^{54}$ AGN, Registro Nacional de Extranjeros, Ingleses, caja 17, Ida Corcoran ingresó al país procedente de La Habana en 1928.
} 
Debido al reducido número de irlandesas en México no contamos con alguna evidencia de su accionar en los ámbitos políticos, sobre todo en las expresiones del nacionalismo, así como la vida comunitaria de la colectividad nacional y/o regional, como si se ha analizado en los Estados Unidos y Argentina, entre otros países. ${ }^{55}$ Dicha limitante consideramos que era subsanada dentro de los ámbitos doméstico y privado, en donde se exteriorizaban y tenían lugar los comentarios y opiniones sobre la vida social del reducido núcleo de irlandeses residentes, las festividades religiosas (San Patricio y/o Santa Brígida, principalmente) y las prácticas de culto, las noticias provenientes de Europa, sobre todo las relativas a la situación política del lugar de origen.

En relación a los varones irlandeses que se establecieron en México habría que precisar dos cuestiones en su perfil laboral. En primer lugar tenemos que una minoría reportó el desempeño de actividades mercantiles y agrícolas, lo que nos lleva a considerar que quienes se ocuparon de tales rubros ya tenían algún tiempo establecidos, como lo evidenció Dionisio José Spillane, que declaró como ocupación ser "hacendado", categoría que presuponía solvencia monetaria para acceder a la propiedad de la tierra, así como la posibilidad de haberse naturalizado mexicano para gozar a cabalidad del carácter de propietario. ${ }^{56}$ Respecto al comercio, si bien los irlandeses no hicieron mención al ramo en que se especializaban, si se advierte en algunos casos que sus negocios tenían tiempo operando o, bien, recién se dedicaban a esta actividad, como Leo Vicente Bealin..$^{57}$

${ }^{55}$ Respecto a la presencia de las irlandesas y el rol social que jugaron como activas actoras del nacionalismo, la educación católica y la vida comunitaria (festividades, beneficencia), lo mismo que su labor como institutrices, monjas y enfermeras en Argentina, entre otros aspectos, véase CRUSET, María Eugenia. Op. Cit., En particular consúltese el capítulo V.

${ }^{56}$ AGN. Registro Nacional de Extranjeros, Ingleses, caja 18, Dionisio José Spillane. En la ficha de registro no se mencionó el nombre de su propiedad, ni la localización de la misma. En este caso es muy probable que Spillane se ocupara de la administración de una finca rústica, como había sucedido con varios de sus antecesores en años anteriores.

${ }^{57}$ AGN, Registro Nacional de Extranjeros, Ingleses, caja 15, Leo Vicente Bealin ingresó al país en septiembre de 1929. Se inscribió en el Registro Nacional de Extranjeros en abril de 1930 declarando 
El segundo factor a considerar y, por ende, a destacar como el principal distintivo de la migración de irlandeses a México respecto a los que les antecedieron en el siglo XIX fue que los que se inscribieron en el Registro Nacional de Extranjeros declararon contar con una preparación técnica y profesional, entre los que se encontraban médicos, contadores, ensayadores químicos, ingenieros civiles y mecánicos, entre otras, a lo que habría que agregar que de acuerdo con sus especialidades hablaban varios idiomas además del inglés, como el español y francés, lo que nos viene a precisar un cambio cualitativo en el perfil del inmigrante. Lo anterior nos confirma su formación en instituciones educativas en Irlanda y la Gran Bretaña. Esta condición nos lleva a plantear que estos irlandeses contaban con opciones viables en la sociedad receptora, lo que de alguna manera podría facilitar su integración. También de acuerdo a las referencias laborales que proporcionaron a las autoridades mexicanas advertimos que su migración fue asistida y dirigida, pues sus referencias o contactos en el país fueron sociedades y compañías británicas en donde prestaban sus servicios, así como empresas norteamericanas.

La minería fue una de las actividades que más llamaron la atención de los irlandeses, entre los que se puede mencionar a Frederick Boyd, ensayador químico, que trabajaba en el mineral de Cata, Guanajuato, atendiendo principalmente el proceso de cianuración de la plata desde 1899, labor que mantenía aún en 1932. ${ }^{58} \mathrm{Al}$ parecer Boyd fue empleado de la compañía norteamericana Guanajuato Reduction and Mines Company. ${ }^{59}$ Por su parte el molinero de metales George Henry Boyd, ${ }^{60}$

como ocupación comerciante, actividad que había desempeñado en siete meses en la ciudad de México. No se especificó el ramo mercantil que atendía.

58 AGN, Registro Nacional de Extranjeros, Ingleses, caja 15, Frederick Boyd Keith.

${ }^{59}$ Sobre los trabajos de la Guanajuato Reduction and Mines Company en el Mineral de Cata véase BLANCO, Mónica. La inversión extranjera en la minería guanajuatence y sus repercusiones. En: Estudios de Historia Moderna y Contemporánea de México. México, n. 17, pág. 45-66, 1996.

${ }^{60}$ AGN, Registro Nacional de Extranjeros, Ingleses, caja 15, George Henry Boyd Hotchkiss nació en Dublín en 1893. A la edad de 34 años viajó a México instalándose en la ciudad de Aguascalientes en 1927. Sobre esta fecha consideramos que muy probablemente exista un error en el registro, ya 
ejerció su especialidad en una de las cinco plantas que la American Smelting and Refining Company que la familia Guggenheim tenía en Aguascalientes. ${ }^{61}$ El caso de Boyd fue representativo, ya que entre 1935 y 1939 laboró en otros centros mineros como Arcelia y Tlacotepec en el estado de Guerrero, así como en San Martín de los Canacos en Oaxaca. Un ejemplo más en este sector industrial lo constituyó el ingeniero civil Eric John Ettles, quien fue contratado en 1950 como supervisor del Departamento de Construcción de la Compañía Minera de Peñoles. ${ }^{62}$

Otra área industrial que atrajo la atención de los irlandeses en México fue la petrolera, sector en el que competían por su control compañías norteamericanas y británicas. Precisamente en las tareas administrativas y técnicas fue donde participaron algunos irlandeses, como Florence H. Driscol Harris, quien desde 1913 era empleado administrativo de la empresa norteamericana Pierce Oil Co., en Tampico, labor que mantuvo hasta $1938 .{ }^{63}$ Por su parte James Millar se desempeñaba como jefe de contabilidad de la Huasteca Petrolium, que era la principal compañía petrolera de origen norteamericano que operaba en el país, propiedad de Edward L. Doheny. ${ }^{64}$ Por lo que respecta a la actuación de irlandeses en empresas petroleras británicas, tenemos que laboraron en la Compañía Mexicana de Petróleo "El Aguila", que formaba parte del grupo Shell. ${ }^{65}$ Entre la planta de trabajadores especializados de "El Aguila" figuró Oliver Brian Holden como ingeniero

que la planta de los Guggenheim en Aguascalientes se cerró en 1925, lo que limitaría las opciones laborales de Boyd, y por lo tanto no se justificaría su estancia en ese lugar.

${ }^{61}$ GÓMEZ SERRANO, Jesús. Aguascalientes. Imperio de los Guggenheim. México: Secretaría de Educación Pública, Fondo de Cultura Económica, 1982.

${ }^{62}$ AGN, Registro Nacional de Extranjeros, Ingleses, caja 17, Eric John Ettles.

${ }^{63}$ AGN, Registro Nacional de Extranjeros, Ingleses, caja 17, Florence Henry Driscoll Harris.

${ }^{64}$ MEYER, Lorenzo, Su Majestad Británica contra la Revolución Mexicana, 1900-1950. El fin de un imperio informal. México: El Colegio de México, 1991, p. 61.

${ }^{65}$ Las particularidades de la trayectoria de Weetman Pearson al frente de la compañía petrolera "El Águila" y su venta al grupo Royal Dutch Shell en 1919 véase en GARNER, Paul, Leones británicos y águilas mexicanas. Negocios, política e imperio en la carrera de Weetman Pearson en México, 1889-1919. México: Fondo de Cultura Económica, Instituto Mora, El Colegio de México, El Colegio de San Luis, 2013. 
químico ${ }^{66}$, mientras que Mathew Monks Gannon, dijo ser empleado en la misma negociación. ${ }^{67}$

La información del censo de población de 1950 fue una de las últimas referencias que nos proporcionan elementos para determinar la presencia en México de irlandeses en nuestro periodo de estudio. Sin embargo esta cuestión nos parece que no es concluyente, ya que en buena parte del seguimiento que hemos realizado sobre este colectivo "inglés", las alusiones al particular han sido poco precisas. Por lo que nos inclinamos a considerar que los irlandeses lejos de abandonar el país, a partir de mediados del siglo XX se mantuvieron y se aglutinaron en torno a la categorización de británicos (britishers). De alguna manera lo anterior se perfila como una posibilidad viable si tomamos en cuenta algunos datos del Anglo-American Directory of Mexico 1949-1950. ${ }^{68}$ En efecto dicho material dista de puntualizarnos la condición de irlandeses tanto de hombres como mujeres de ese origen, ya que se concentran bajo la condición, como arriba lo mencionamos de británicos, con la salvedad de pocos casos en donde se precisó su lugar de origen. A manera de ejemplo se podría considera a Ida Esme Corcoran, quien se desempeñaba como secretaría del vicepresidente del National City Bank of New York en la ciudad de México. ${ }^{69}$

\section{A manera de conclusión}

De acuerdo a las particularidades de los intereses económicos británicos en México en el siglo XIX su presencia se hizo presente en diversos niveles, como lo fue el ámbito diplomático, la inversión de capitales en la minería, el comercio y la deuda pública, cuyos resul-

\footnotetext{
${ }^{66}$ AGN, Registro de Extranjeros, Ingleses, caja 8, Oliver Brain Holden. Holden era originario de Dublín, en donde nació en 1903, arribó a México en 1923 a la edad de 26 años. De acuerdo a la fecha de su inscripción en el Registro Nacional de Extranjeros en 1933, ya tenía trabajando para "El Águila" siete años.

${ }^{67}$ AGN, Registro Nacional de Extranjeros, Ingleses, caja 12, Mathew Monks Gannon.

${ }^{68}$ Anglo-American Directory of Mexico 1949-1950. México: Imprenta Nuevo México, 1950.

${ }^{69}$ Anglo-American Directory of Mexico 1949-1950. México: Imprenta Nuevo México, 1950, p. 34.
} 
tados fueron contrastantes. ${ }^{70} \mathrm{El}$ carácter específico de los rubros que los ingleses atendieron en la capital del país, lo mismo que en diversos centros urbanos del interior, denota la participación de personal especializado cuya presencia se puede advertir como transitoria y, por lo tanto, alejada de aspiraciones migratorias formales. Una de esas variantes la constituyen mayor o menor medida los irlandeses a partir de la década de 1840. El migrante irlandés que eligió México como lugar de trabajo y residencia permanente a primera vista difiere del perfil de que optó por los Estados Unidos, como se desprende en el desarrollo de este trabajo.

A manera de conclusión podemos decir que el seguimiento que hemos hecho a los irlandeses que se establecieron en México entre 1900 y 1950 a través de las tarjetas del Registro Nacional de Extranjeros, constituye un primer acercamiento al estudio de este colectivo no nacional. Esta aproximación nos ha permitido determinar su número, lugar de procedencia, composición por sexos, edad, ocupación, lugares de residencia en el país, etc., lo que nos conduce a plantear que los irlandeses fueron un componente minoritario dentro de la migración inglesa tanto en el siglo XIX como en las primeras cinco décadas del XX. Respecto al carácter general de la inmigración de irlandeses sobresale el que la compongan individuos en edad adulta que oscilaron entre los 30 y 50 años, lo que plantea que el objetivo de su estancia no era el inicio de una vida económicamente activa que por lo general se hacía a muy temprana edad, sino que había otro tipo de factores que la alentaban, como el reencuentro familiar, y el empleo previamente contratado, lo que limitaba el fracaso y retorno al lugar de origen con ciertos recursos ahorrados.

La presencia de mujeres irlandesas nos propone variantes en cuanto a su desempeño en la sociedad receptora, ya bien por que cumplía

\footnotetext{
${ }^{70}$ Sobre el particular véase JIMÉNEZ CONDINACH, Guadalupe. La Gran Bretaña y la independencia de México 1808-1821. México. Fondo de Cultura Económica, 1991; COSTELOE, Michael P. Deuda externa de México. Bonos y tenedores de bonos 1824-1888. México: Fondo de Cultura Económica, 2007.
} 
con un rol tradicional dentro del hogar, o bien porque se tratara de mujeres solteras que ejercían alguna profesión, que les brindaba los medios de subsistencia. En este caso la soltería de muchas irlandesas nos lleva a considerar que no había en su entorno inmediato suficientes hombres de esa nacionalidad con los cuales pudieran contraer matrimonio, ya que la mayoría eran casados. Esta situación, a diferencia de los hombres que si se unían con mujeres mexicanas, nos habla en buena medida de tendencias endogámicas femeninas.

$\mathrm{El}$ principal rasgo que podemos destacar en la migración irlandesa en México en la primera mitad del siglo XX fue la especialización técnica y profesional que se observó en los hombres. Esta situación les facilitó el acceso a actividades remuneradas, sobre todo en compañías mineras y petroleras inglesas y norteamericanas. Esta característica a su vez abrió la opción de una nueva vía migratoria como era la migración asistida, o que en su defecto el trabajador había sido previamente contratado en el lugar de origen por alguna de las sociedades y compañías en las que más tarde prestaría sus servicios.

\section{Bibliografía}

BADE, KLAUS J. Europa en movimiento. Las migraciones desde finales del siglo XVIII hasta nuestros días. Barcelona: Crítica, 2003.

BARCELÓ QUINTAL, Raquel Ofelia. Ingleses en Real del Monte: tejiendo identidades (1824-1910). En: _ _ (coord.). Extraños en tierra ajena. Migración, alteridad e identidad, siglos XIX y XX. México: Plaza y Valdés, 2009.

BERNINGER, Dieter George. La inmigración en México (1821-1857). México: Secretaría de Educación Pública, 1974.

CERUTTI, Mario. Burguesía y capitalismo en Monterrey (1850-1890). México; Claves Latinoamericanas, Facultad de Filosofía y Letras, Universidad Autónoma de Nuevo León, 1989.

CERUTTI, Mario. El préstamo prebancario en el noreste de México: la actividad de los grandes comerciantes de Monterrey (1855-1890). En: LUDLOW, Leonor y Carlos MARICHAL (eds.). Banca y poder en México (1800-1925). México: Grijalbo, 1986. p. 119-164.

CERUTTI, Mario. Patricio Milmo, empresario regiomontano del siglo XIX. 
En. CARDOSO, Ciro F. S. Formación y desarrollo de la burguesía en México. Siglo XIX. México: Siglo XXI Editores, 1979. p. 231-266.

CONNOLLY, Priscila. El contratista de don Porfirio. Obras públicas, deuda y desarrollo desigual. México: El Colegio de Michoacán, Universidad Autónoma Metropolitana/Azcapotzalco, Fondo de Cultura Económica 1997.

COSTELOE, Michael P. Deuda externa de México. Bonos y tenedores de bonos 1824-1888. México: Fondo de Cultura Económica, 2007.

CRUSET, María Eugenia. Nacionalismo y diásporas. Los casos vasco e irlandés en Argentina (1862-1922). Buenos Aires: Universidad Nacional de La Plata, Cátedra Libre de Pensamiento y Cultura Irlandesa, Ediciones Lauburu, 2015.

DUBY, George y PERROT, Michelle (dirs.). Historia de las mujeres en occidente. Madrid: Taurus, Tomos IV y V, 2000.

GALLAHGER, Thomas. Hambre en Irlanda: la elegía de Paddy. Madrid: Langre, 2007.

GAMBOA OJEDA, Leticia. Los españoles en la ciudad de Puebla hacia 1930. En: LIDA, Clara E. (comp.). Una inmigración privilegiada. Comerciantes, empresarios y profesionales españoles en México en los siglos XIX y XX. Madrid: Crítica, 1994, p. 190-217.

GAYÓN GÓRDOVA, María. Extranjeros en la ciudad de México en 1848. En: SALAZAR ANAYA, Delia (coord.). Imágenes de los inmigrantes en la ciudad de México, 1753-1910. México: Plaza y Valdés Editores, CONAGULTA, INAH, 2002.

GÓMEZ SERRANO, Jesús. Aguascalientes. Imperio de los Guggenheim. México: Secretaría de Educación Pública, Fondo de Cultura Económica, 1982

GONZÁLEZ NAVARRO, Moisés. Los extranjeros en México y los mexicanos en el extranjero 1821-1970. México: El Colegio de México, 1993. vol. I.

HERRERA GANALES, Inés. Comercio y comerciantes en la costa del Pacífico a mediados del siglo XIX. Historias, México, n. 20, pág. 133-134, 1988.

HERRERA CANALES, Inés. Mercurio para refinar la plata mexicana en el siglo XIX. Historia Mexicana, México, vol. XL, n. 1, pág. 27-51, 1990. 
HERRERA, Inés (et al). Etnia y clase. Los trabajadores ingleses de la Compañía del Real del Monte y Pachuca, 1824-1906. México: INAH, 1981.

JIMÉNEZ GONDINACH, Guadalupe. La Gran Bretaña y la independencia de México 1808-1821. México. Fondo de Gultura Económica, 1991.

LIDA, CLARA E. Inmigración y exilio. Reflexiones sobre el caso español. México: Siglo XXI Editores, 1997

LUNA JIMÉNEZ, Pedro y Mario CONTRERAS VALDEZ. Las inversiones extranjeras en Nayarit. En OLVEDA, Jaime (ed.). Inversiones y empresarios extranjeros en el noroccidente de México, siglo XIX. Guadalajara: El Colegio de Jalisco, 1998.

LYNCH BRENNAN, Margaret. The irish bridget: irish inmigrant women in domestic service in America, 1840-1930. New York: Syracuse University Press, 2009.

LYON, G. F. Residencia en México. 1826. Diario de una gira con estancia en la República de México. México: Fondo de Cultura Económica, 1984.

MEYER, Lorenzo, Su Majestad Británica contra la Revolución Mexicana, 1900-1950. El fin de un imperio informal. México: El Colegio de México, 1991.

MORALES, María Dolores. La población extranjera en la ciudad de México en 1882. En: SALAZAR ANAYA, Delia (coord.). Imágenes de los inmigrantes en la ciudad de México, 1753-1910. México: Plaza y Valdés Editores, CONACULTA, INAH, 2002.

MORISON, Samuel Eliot (et al). Breve Historia de los Estados Unidos. México: Fondo de Cultura Económica, 1987.

PARRA, Alma Laura. Presencia inglesa en México durante el siglo XIX. Historias, México, n.33, pág. 13-20, 1995.

PÉREZ ACEVEDO, Martín. Inmigrantes transatlánticos en México durante el Porfiriato: algunas consideraciones para un estado de la cuestión. En: RODRÍGUEZ DÍAZ, María del Rosario y RIVERA REYNALDOS, Lisette Griselda (coords.). El Porfiriato y la Revolución Mexicana. Construcciones sociales, instituciones políticas y miradas desde la historiografía. Morelia: Universidad Michoacana de San Nicolás de Hidalgo, 2012.

PLA, Dolores Y ZÁRATE, Guadalupe (et al). Extranjeros en México (18211990). Bibliografía. México: INAH, 1994.

RANDALL, Robert W. Real del Monte: una empresa minera británica en 
México. México: Fondo de Cultura Económica, 1986.

SALAZAR ANAYA, Delia. Extraños en la ciudad. Un acercamiento a la inmigración internacional a la ciudad de México, en los censos de 1890, 1895, 1900 y 1910- En __(coord..). Imágenes de los inmigrantes en la ciudad de México, 1753-1910. México: Plaza y Valdés Editores, CONACULTA, INAH, 2002. p. 225-250.

SALAZAR ANAYA, Delia. La población extranjera en México (1895-1990). Un recuento con base en los Censos Generales de Población. México: INAH. 1996.

Recebido: 16/05/2017 - Aprovado: 21/08/2017 